\title{
Antioxidant Activity and Lipoxygenase Enzyme Inhibitory Assay with Total Flavonoids Content from Garcinia hombroniana Pierre Stem Bark Extract
}

\author{
Amanda Listiyani, Berna Elya*, Nuraini Puspitasari
}

\begin{abstract}
Introduction: Garcinia has been known as a rich source of xanthones, flavonoids, and phenols. The aim of this research is to obtain data of antioxidant activity and to observe potential inhibition of lipoxygenase activity that most active from methanolic, ethyl acetate and $n$-hexane extracts with total flavonoids content from most active extracts from the bark of Garcinia hombroniana Pierre. Methods: The antioxidant activity was measured using the ferric reducing antioxidant power (FRAP), the anti-inflammatory assay was measured using inhibition of lipoxygenase activity test, qualitative analysis of flavonoids using thin layer chromatography, and total flavonoids content was measured using $\mathrm{AlCl}_{3}$ colorimetric method. Results: The results showed that the ethyl acetate extract from $\mathrm{G}$. hombroniana Pierre stem bark as the most active extract for antioxidant and lipoxygenase inhibition activity with $\mathrm{EC}_{50}$ and $\mathrm{IC}_{50}$ value consecutively $15.34 \mu \mathrm{g} / \mathrm{ml} ; 0.26 \mu \mathrm{g} / \mathrm{ml}$. Total flavonoids content of ethyl acetate is $7.430 \mathrm{mg} \mathrm{OE} / \mathrm{g}$ extract. The results of this study showed bark extract Garcinia hombroniana Pierre has antioxidant activity and potent to inhibit lipoxygenase activity. Conclusion: Based on the research for methanolic, ethyl acetate and n-hexane extract, it can be concluded that the ethyl acetate extract of $G$. hombroniana Pierre as the most active extract for antioxidant and lipoxygenase inhibition activity.
\end{abstract}

Key words: Antioxidant, Garcinia hombroniana Pierre, Inflammation, Lipoxygenase, Total flavonoids content.
Amanda Listiyani, Berna Elya*, Nuraini Puspitasari

Department of Pharmacognosy-

Phytochemistry, Faculty of Pharmacy,

Universitas Indonesia, Kampus Baru UI

Depok, 16424, Depok, INDONESIA.

Correspondence

Berna Elya

Faculty of Pharmacy, Universitas Indonesia, Gedung A Rumpun IImu Kesehatan Lantai 1, Kampus UI, Depok, Jawa Barat - 16424, INDONESIA.

Phone: +62 217270031

E-mail: berna.elya@gmail.com

History

- Submission Date: 21-12-2016;

- Review completed: 05-01-2017;

- Accepted Date: 16-01-2017.

DOI : 10.5530/pj.2017.2.47

Article Available online

http://www.phcogj.com/v9/i2

\section{Copyright}

(C) 2017 Phoog.Net. This is an openaccess article distributed under the terms of the Creative Commons Attribution 4.0 International license.

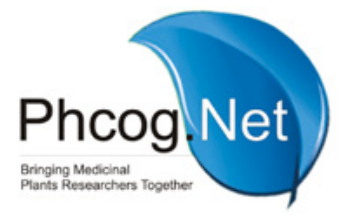

\section{INTRODUCTION}

Garcinia is a plant that rich source of secondary metabolites, especially xanthones, flavonoids, and polyphenols. ${ }^{1}$ A wide variety of biological and pharmacological activity have been reported such as anti-HIV, anti-cancer, antioxidant, anti-tuberculosis, anti-fungal, antibacterial, anti-inflammatory, and anti-Alzheimer ${ }^{2}$ Anti-inflammatory activities showed in the presence of 12-lipoxygenase inhibition by a-mangostin from Garcinia mangostana with $\mathrm{IC}_{50}$ was $0.58 \mu \mathrm{M} .^{3}$ Garcinia hombroniana Pierre is a native plant from Sumatra. At this time, G. hombroniana Pierre has been cultivated in Bogor Botanical Garden, West Java. Some constituents were identified as lupeol acetate, $\beta$-sitosterol, xanthones, leucodin, betulin, betulinic acid, and stearic acid ${ }^{4}$ that may be used for treatments.

The previous study provides that G. hombroniana Pierre stem bark extract has antioxidant activity (ethyl acetate extract 5579.8 \pm 117.77 ; methanol extract $4709.6 \pm 88.0$; n-hexane extract $<2000 \mathrm{~mol} \mathrm{TE} / \mathrm{g}$ ), anti-cholinesterase, and anti-bacterial. Traditionally, this plant also used as anti-inflammatory. Total flavonoids content of $G$. hombroniana Pierre was 3317.6 $\pm 131.0 \mathrm{QE}$ (quercetin equivalent)/g extract. ${ }^{2}$ However, few studies that discuss anti-inflammatory and antioxidant activity using Ferric reducing antioxidant power (FRAP) method of G. hombroniana Pierre. Therefore, further research to determine the inhibi- tion of lipoxygenase activity and antioxidant activity using FRAP. Furthermore, the phytochemical screening using thin layer chromatography (TLC) and total flavonoids contents at the most active extracts also discussed in this study.

\section{MATERIAL AND METHODS}

\section{Antioxidant Activity Assay using FRAP Method}

FRAP assay was done according to the method described by Benzie and Strain $(1996)^{5}$ with some modifications. Working solution of FRAP was prepared by mixing $300 \mathrm{mM}$ acetate buffer ( $\mathrm{pH}$ 3.6), $10 \mathrm{mM}$ 2,4,6-tripyridyl-s-triazine (TPTZ) (SigmaAldrich) in $40 \mathrm{mM} \mathrm{HCl}$ and $220 \mathrm{mM} \mathrm{FeCl}_{3} 6 \mathrm{H}_{2} \mathrm{O}$ (10:1:1). 3.8 ml FRAP reagent solution reacted with $0.2 \mathrm{ml}$ baicalein solution or sample, then incubated for 30 minutes at $37^{\circ} \mathrm{C}$. For sample or standard control, $3.8 \mathrm{ml}$ FRAP reagent solution reacted with $0.2 \mathrm{ml}$ ethanol pro analysis, then treated the same as well as the sample or standard. The absorbance of the product was then measured at $595 \mathrm{~nm}$. The percentage of capacity can be calculated using \% capacity calculation. The analysis was done in triplicate. The result was expressed as $\mathrm{EC}_{50}(\mu \mathrm{g} / \mathrm{ml})$, and obtained by using Microsoft Office Excel or GraphPad Prism 7. 


\section{Lipoxygenase Enzyme Inhibition Assay}

Preliminary test consist of optimization of borate buffer $(\mathrm{pH} 8 ; 8.5 ; 9$; $9,5)$, stop solution ( $1 \mathrm{ml}$ of methanol), enzyme concentration (2500; 5000; 7500; and 10000 units $/ \mathrm{ml})$ and substrate concentration $(300 ; 600$; $900 ; 1200 ; 1500 \mu \mathrm{M})$. The lipoxygenase assay was performed by reacting $10 \mathrm{ml}$ of baicalein (Sigma-Aldrich) or sample solution (with various concentration), $1690 \mu \mathrm{l}$ of $0.2 \mathrm{M}$ borate buffer ( $\mathrm{pH} 8.5$ ), $1000 \mu \mathrm{l}$ of a linoleic acid substrate (Sigma-Aldrich) $(900 \mu \mathrm{M})$. Incubated for $10 \mathrm{~min}$ at $25^{\circ} \mathrm{C} .300 \mu \mathrm{l}$ of lipoxygenase solution $(5000 \mathrm{units} / \mathrm{ml})$ was added and incubated $15 \mathrm{~min}$ at $25^{\circ} \mathrm{C} .1000 \mu \mathrm{l}$ of stop solution added and measured its absorbance using UV-Vis spectrophotometer at $235 \mathrm{~nm}$. Analysis was done in triplicate

Inhibition of the activity of lipoxygenase calculated using the following equation:

$\%$ lipoxygenase inhibition $=\frac{(\mathrm{A}-\mathrm{B})-(\mathrm{C}-\mathrm{D})}{(\mathrm{A}-\mathrm{B})} \times 100 \%$

$A=$ Absorbance of reference solution with enzyme

$\mathrm{B}=$ Absorbance of reference solution without enzyme

$\mathrm{C}=$ Absorbance of standard or sample solution with enzyme

$\mathrm{D}=$ Absorbance of standard or sample solution without enzyme

The result was expressed as $\mathrm{IC}_{50}(\mu \mathrm{g} / \mathrm{mL})$, and obtained by using Microsoft Office Excel or GraphPad Prism 7.

\section{Phytochemical Screening using Thin Layer Chromatography}

Thin Layer Chromatography analysis for methanolic, ethyl acetate, and n-hexane extract using mobile phase that has been optimized. Stationary phase using silica gel $60 \mathrm{~F}_{254}$ plates. Mobile phase for methanolic extract is ethyl acetate-formic acid (4:0.2), toluene-ethyl acetate-formic acid (61: 30: 9) for extract ethyl acetate and n-hexane-ethyl acetate (6:4) for extract $n$-hexane. each extract solution was spotted on a TLC plate. TLC plates which had been eluted dried and sprayed with $\mathrm{AlCl}_{3} 5 \%$ to analyze the presence of flavonoids compounds. The plates were examined under UV light at a wavelength of $254 \mathrm{~nm}$ and $366 \mathrm{~nm}$. Quercetin is used as the reference standard that treated similarly to extract. Determined the Rf between quercetin and sample.

\section{Determination of Total Flavonoids Content (TFC)}

Total flavonoid content was measured using the modified method adapted from Chang et al. ${ }^{6}$ The most active extract in antioxidant activity and inhibition of lipoxygenase highest measured the total flavonoids content. Prepared samples $(0.5 \mathrm{ml})$ by reacting $1.5 \mathrm{ml}$ of methanol $95 \%(\mathrm{v} / \mathrm{v}), 0.1$ $\mathrm{ml}$ of $10 \%$ aluminum chloride ( $\mathrm{w} / \mathrm{v}), 0.1 \mathrm{ml}$ of $1 \mathrm{M}$ sodium acetate, and $2.8 \mathrm{ml}$ of distilled water. The mixture samples were incubated at a temperature of $\pm 25^{\circ} \mathrm{C}$ for $30 \mathrm{~min}$. The absorbance was read at wavelength $435 \mathrm{~nm}$. The analysis was done in triplicate. Quercetin is used as a standard with the same treatment as the samples for the calibration curve. The total flavonoid content was reported as total quercetin equivalent per g extract (mg QE/ g extract).

\section{RESULT}

\section{Antioxidant Activity Assay using FRAP Method}

FRAP method is based on the ability of antioxidants to reduce $\mathrm{Fe}^{3+}$ to $\mathrm{Fe}^{2+}$ in the presence of 2,4,6-tri (2-pyridyl) -s triazine (TPTZ), forming intense blue color of the complex $\mathrm{Fe}^{2+}$-TPTZ that measured in maximum absorbance at $595 \mathrm{~nm} .^{7}$ This reaction depends on $\mathrm{pH}$ (optimum $\mathrm{pH}$ was 3.6). ${ }^{8}$ FRAP methods performed at acidic $\mathrm{pH}$ conditions (3.6) for an iron solubility and the most important is to facilitate the transfer of

electrons, thereby increasing the redox potential. ${ }^{9}$ FRAP methods using reagents tripyridyl triazine (TPTZ) as an iron-binding ligand. FRAP test is a method that is simple, fast, and cheap enough and does not require special equipment. ${ }^{10}$ Antioxidant capacity was expressed as $\mathrm{EC}_{50} \mathrm{EC}_{50}$ is a concentration of sample or standard that can exhibit $50 \%$ of FRAP capacity. From the experiments, data showed the $\mathrm{EC}_{50}$ of baicalein (positive control), ethyl acetate extract, methanolic extract, and n-hexane extract respectively $1.16 ; 15.34 ; 27.21$, and $110.9 \mu \mathrm{g} / \mathrm{ml}$. Ethyl acetate as the most active extract because has the lowest $\mathrm{EC}_{50}$ value but less potent than baicalein as a positive control. Sequentially, that has the highest antioxidant activity then was baicalein $>$ ethyl acetate extracts $>$ methanolic extract $>$ n-hexane extract.

\section{Lipoxygenase Enzyme Inhibition Assay}

From the preliminary test obtained data for optimum conditions for lipoxygenase enzyme inhibition assay, there was 8.5 for optimum $\mathrm{pH}, 1$ $\mathrm{ml}$ of methanol for stop solution, $5000 \mathrm{U} / \mathrm{ml}$ for enzyme concentration, and $900 \mu \mathrm{M}$ for substrate concentration. The result showed that $\mathrm{IC}_{50}$ of baicalein, methanolic extract, ethyl acetate extract, n-hexane extract respectively $0.24 ; 0,26 ; 0.95 ; 5.09 \mu \mathrm{g} / \mathrm{ml}$. Ethyl acetate as the most active extract because has the lowest $\mathrm{IC}_{50}$ value but less potent than baicalein as a positive control. The previous study reported that Garcinia contains xanthones and benzophenone derivative, and rich in flavonoids that have anti-inflammatory activity. ${ }^{11}$

\section{Phytochemical Screening using Thin Layer Chromatography}

Analysis using thin layer chromatography was used for screening the presence of flavonoids. The results showed that ethyl acetate and methanolic extract contains flavonoid that proved by yellow color in silica gel plates at $366 \mathrm{~nm}$ while $\mathrm{n}$-hexane doesn't. The yellow color in ethyl acetate extract is more and intensive than methanolic extract. The result corresponded in antioxidant activity and lipoxygenase inhibition assay that state the ethyl acetate as the most active extracts. The result can be seen in Figure 1, 2 and 3.

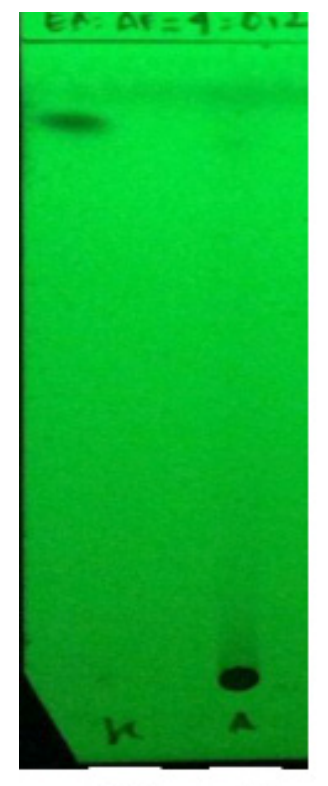

K M

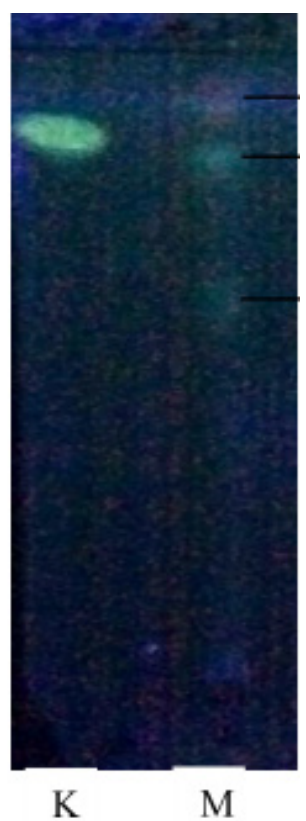

Figure 1: Spot of methanolic extract. $K=$ quercetin; $M=$ methanolic extract. Conditions: stationary phase silica gel $\mathrm{F}_{254}$ and the mobile phase ethyl acetate-formic acid (4: 0.2) at $254 \mathrm{~nm}$ UV light (a) and $366 \mathrm{~nm}$ (b) after being sprayed with $\mathrm{AlCl}_{3} 5 \%$. 


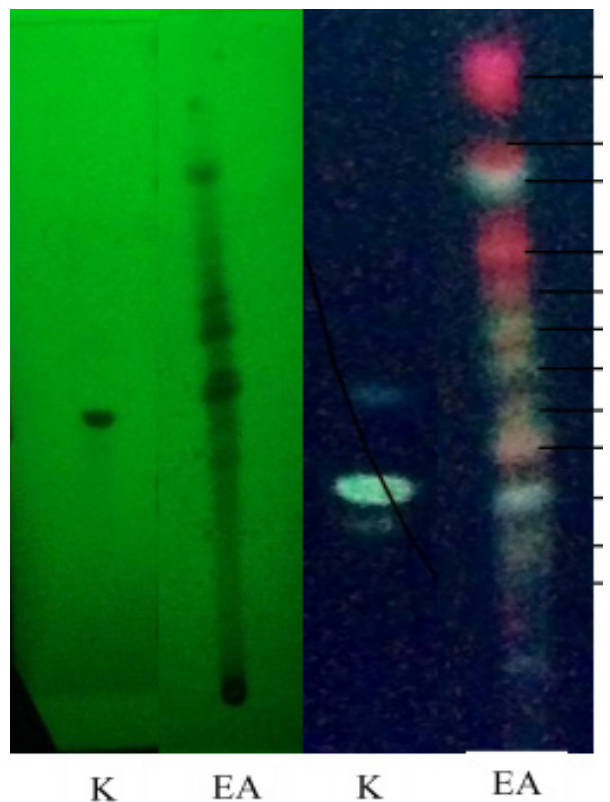

(a)

(b)

Figure 2: Spot of ethyl acetate extract. $\mathrm{K}$ = quercetin; $\mathrm{EA}=$ ethyl acetate extract. Conditions: stationary phase silica gel $\mathrm{F}_{254}$ and the mobile phase toluene-ethyl acetate-formic acid (61: 30: 9) at $254 \mathrm{~nm}$ UV light (a) and 366 $\mathrm{nm}$ (b) after being sprayed with $\mathrm{AlCl}_{3}$ to $5 \%$.

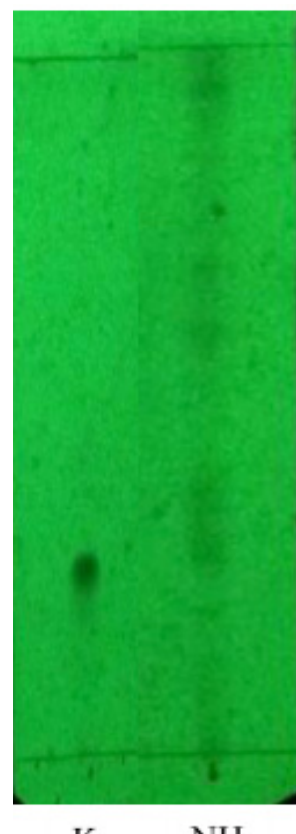

$\mathrm{K}$ (a)

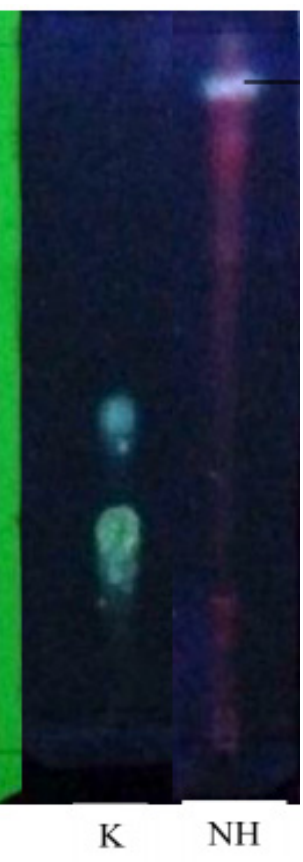

(b)
Figure 3: Spot of $\mathrm{n}$-hexane extract. $\mathrm{K}=$ quercetin; $\mathrm{NH}=\mathrm{n}$-hexane extract. Conditions: stationary phase silica gel $\mathrm{F}_{254}$ and the mobile phase $\mathrm{n}$-hexane-ethyl acetate (6: 4) at $254 \mathrm{~nm}$ UV light (a) and $366 \mathrm{~nm}$ (b) after being sprayed with $\mathrm{AlCl}_{3}$ to $5 \%$.

\section{Determination of Total Flavonoids Content (TFC)}

The total flavonoids contents were measured by using $\mathrm{AlCl}_{3}$ colorimetric method for ethyl acetate extract. The principle of determination of the flavonoid content consists in the fact that aluminum chloride forms stable acid complexes with the carbonyl group at $\mathrm{C} 4$ and hydroxyls at C3 (flavonols) and C5 in flavonols and flavones, besides forming labile acid complexes with hydroxyls in the ortho position in $\mathrm{A}$ or $\mathrm{B}$ rings of flavonoids. ${ }^{6}$ Obtained linear regression $0,0431 \mathrm{x}+\mathrm{y}=0.1394$ from calibration curve of quercetin, with $\mathrm{R}^{2}=0.9957$ According to the formula ${ }^{12}$ total flavonoids content of ethyl acetate extract is of $7.430 \mathrm{mg} \mathrm{QE}$ (quercetin equivalents / g extract).

\section{CONCLUSION}

Based on the research for methanolic, ethyl acetate and n-hexane extract, it can be concluded that the ethyl acetate extract of $G$. hombroniana Pierre as the most active extract for antioxidant and lipoxygenase inhibition activity with $\mathrm{EC}_{50}$ and $\mathrm{IC}_{50}$ value consecutively $15.34 \mu \mathrm{g} / \mathrm{ml} ; 0.26 \mu \mathrm{g} /$ $\mathrm{ml}$. Total flavonoids content of ethyl acetate is $7.430 \mathrm{mg}$ QE/g extract. However, there should be more research for ethyl acetate extract as the most active extract include isolation and characterization of compounds.

\section{ACKNOWLEDGMENTS}

This study was supported by the Ministry of Research and Technology, Republic of Indonesia and Directorate of Research and Community Engagement, Universitas Indonesia via Hibah PITTA 2016.

\section{CONFLICT OF INTEREST}

No conflict of interest are declared.

\section{REFERENCES}

1. Jantan I, Jumuddin FA, Saputri FC, Rahman K. Inhibitory Effects of the Extracts of Garcinia species on Human Low-Density Lipoprotein Peroxidation and Platelet Aggregation in Relation to Their Total Phenolic Contents. Journal of Medicinal Plants Research. 2010;5(13):2699-709.

2. Nargis J. Antioxidant, Anticholinesterase and Antibacterial Activities of The bark Extracts of Garcinia hombroniana. African Journal of Pharmacy and Pharmacology. 2013;7(8):454-9. https://doi.org/10.5897/AJPP12.944.

3. Pedraza-chaverri J, Cárdenas-rodríguez N, Orozco-ibarra M, Pérez-rojas JM Medicinal Properties of Mangosteen (Garcinia mangostana). Food and Chemical Toxicology. 2008;46(10):3227-39. https://doi.org/10.1016/j.fct.2008.07.024 PMid:18725264.

4. Jamila N, Khairuddean M, Khan SN, Khan N, Osman H. Phytochemicals from The Bark of Garcinia hombroniana and Their Biological Activities. Records of Natural Products. 2014;8(3):312-6.

5. Benzie IF, Strain JJ. The ferric reducing ability of plasma (FRAP) as a measure of "antioxidant power" the FRAP assay. Analytical Biochemistry. 1996;239:70-6. https://doi.org/10.1006/abio.1996.0292 PMid:8660627.

6. Chang $\mathrm{CH}$, Yang $\mathrm{MH}$, Wen HM, Chern JC. Estimation of Total Flavonoid Content in Propolis by Two Complementary Colorimetric Methods. Journal of Food and Drug Analysis. 2002;10(3):178-82.

7. Salini S, Chubicka T, Sasidharan N, Sindhu ER, Babu TD. Cytotoxic and Antioxidant Properties of Selected Scutellari A Species from The Western Ghats of Peninsular India. Pharmaceutical Biology. 2013;51(2):152-9. https://doi.org/10.3 109/13880209.2012.715170 PMid:23127222

8. Chanda S, Dave R. In vitro Models for Antioxidant Activity Evaluation and Some Medicinal Plants Possessing Antioxidant Properties : An overview. African Journal of Microbiology Research. 2009;3(13):981-96.

9. Gulcin I. Antioxidant Activity of Food Constituents: An Overview. Archive in Toxicology.2012;86(3):345-91. https://doi.org/10.1007/s00204-011-0774-2 PMid:22102161.

10. Shahidi F, Zhong Y. Measurement of Antioxidant Activity. Journal of Functional Foods. 2015;18:757-81. https://doi.org/10.1016/j.jff.2015.01.047.

11. Paul J, Meli A, Fouotsa H, Djama C, Ephrem A, Sewald N, et al. Anti-inflammatory Activity of Benzophenone and Xanthone Derivatives Isolated from Garcinia ( Clusiaceae ) species. Phytochemistry Letters. 2015;14:153-8. https://doi. org/10.1016/j.phytol.2015.10.003.

12. Bhaigyabati T, Devi PG, Bag GC. Total flavonoids Content and Antioxidant Activity of Aqueous Extract of Rhizome Three Hedychium Species of Manipur Valley. Research Journal of Pharmaceutical Biological and Chemical Sciences. 2014;5(5):970-6. 


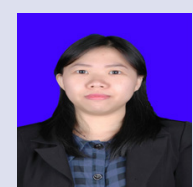

\section{ABOUT AUTHORS}

Amanda Listyani: Undergraduate Student from Faculty of Pharmacy, University of Indonesia Enrolling Apothecary Program in Faculty of Pharmacy University of Indonesia

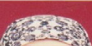
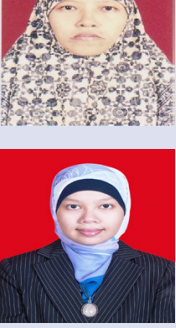

Elya: Lecturer, Researcher, and Laboratory of Phytochemistry and Pharmacognosy, Faculty of Pharmacy, Universitas

Puspitasari: Lecturer, Researcher, and Laboratory of Phytochemistry and Pharmacognosy, Faculty of Pharmacy, Universitas

Cite this Article: Listiyani A, Elya B, Puspitasari N. Antioxidant Activity and Lipoxygenase Enzyme Inhibitory Assay with Total Flavonoids Content from Garcinia hombroniana Pierre Stem Bark Extract. Pharmacogn J 2017;9(2):276-9. 